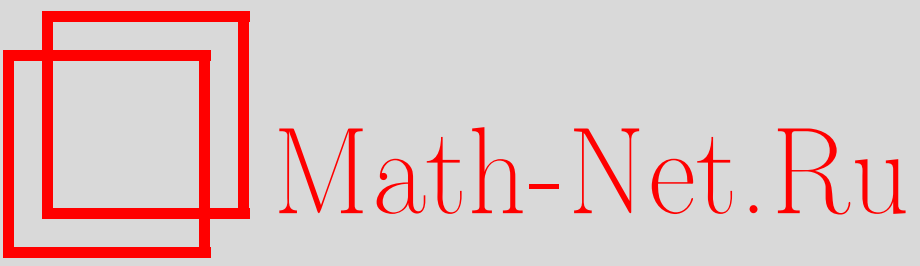

Седьмой китайский симпозиум по предельным теоремам теории вероятностей и асимптотической теории для больших выборок в статистике, Теория вероятн. и ее примен., 2012, том 57, выпуск 1, 204-205

DOI: https://doi.org/10.4213/tvp4442

Использование Общероссийского математического портала Math-Net.Ru подразумевает, что вы прочитали и согласны с пользовательским соглашением

http: //www . mathnet.ru/rus/agreement

Параметры загрузки :

IP : 54.80 .73 .141

26 апреля 2023 г., 17:39:39 


\title{
СЕДЬМОЙ КИТАЙСКИЙ СИМПОЗИУМ ПО ПРЕДЕЛЬНЫМ ТЕОРЕМАМ ТЕОРИИ ВЕРОЯТНОСТЕЙ И АСИМПТОТИЧЕСКОЙ ТЕОРИИ ДЛЯ БОЛЬШИХ ВЫБОРОК В СТАТИСТИКЕ
}

\author{
(перевод В.В. Ульянова)
}

Седьмой китайский симпозиум по предельным теоремам теории вероятностей и асимптотической теории для больших выборок в статистике состоялся с 4-го по 7-е ноября 2011 г. в Уханьском университете провинции Хубэй, где протекает знаменитая река Янцзы. Подобные конференции проводятся каждые два года, начиная с 1999 г. Их инициатор - статистик с мировой известностью действительный член Китайской академии наук Ксиру Чен (Xiru Chen). Две предыдущие конференции проходили в Лояне, провинция Хэнань, в 2009 г. и в Чжэньцзяне, провинция Цзянсу, в 2007 г.

Уханьский симпозиум продолжил традицию таких конференций. В состав программного комитета симпозиума входили Хуа Чен (Нua Chen) (Уханьский университет), Чженян Лин (Zhengyan Lin) (Чжецзянский университет), Байки Мяо (Baiqi Miao) (Китайский университет науки и технологий), Ки Ман Шао (Qiman Shao) (Гонконгский университет науки и технологий), Чун Сy (Chun Su) (Китайский университет науки и технологий). Всего в работе симпозиума приняли участие около 120 ученых. Церемонией открытия руководил председатель местного организационного комитета Юн Ху (Yijun Hu), заместитель декана колледжа математики и статистики Уханьского университета. Чженян Лин, член Международного статистического института и известный специалист в области теории вероятностей и математической статистики обратился к участникам со вступительной речью, в которой он напомнил историю симпозиумов, а затем сформулировал основные цели текущего симпозиума. Он также подчеркнул, что ему очень приятно видеть в аудитории так много молодых лиц.

В последние десятилетия в Китае наблюдался значительный прогресс в развитии предельных теорем теории вероятностей и их приложений в статистике и экономике. В частности, ученые из Чжецзянского университета и Китайского университета науки и технологий получили замечательные результаты в области классических предельных теорем для сумм независимых, а также зависимых (в терминах условий перемешивания) случайных величин и для приращений траекторий случайных процессов. Одной из основных целей симпозиума было обсуждение новейших результатов в области предельных теорем теории вероятностей и асимптотической статистической теории и их приложений. После церемонии открытия были заслушаны семь 45-минутных докладов приглашенных докладчиков: Владимира Ульянова (Московский государственный университет им.М.В.Ломоносова), Чжи Су Ху (Zhishui $\mathrm{Hu}$ ) (Китайский университет науки и технологий), Вон Чжоу (Wang Zhou) (Национальный университет Сингапура), Бин Джи Ин (Bingyi Jin) (Гонконский университет науки и технологий), Ли Хи Чжан (Lixin Zhang) (Чжецзянский университет), Вэй Дон Лю (Weidong Liu) (Университет Джиа Тон в Шанхае), Хи Чен Чжан (Xicheng Zhang) (Уханьский университет). В докладах освещались достижения в исследовании различных задач теории вероятностей и прикладной статистики, связанных, в частности, с критериями согласия в статистике, сильной аппроксимацией и слабой сходимостью для самонормированных статистик, асимптотическим оцениванием случайных 
ковариационных матриц большой размерности, анализом высокочастотных финансовых данных, ответ-адаптивным дизайном в клинической медицине, стохастическими дифференциальными уравнениями с негладкими коэффициентами.

Помимо приглашенных докладчиков участники симпозиума на двух секциях заслушали более двадцати сообщений о других новейших результатах. Значительное внимание уделялось таким бурно развивающимся в последнее время направлениям, как случайные деревья, марковские цепи высокого порядка, случайные матрицы большой размерности. В ряде докладов рассматривались новые приложения стохастического анализа и предельных теорем теории вероятностей в финансовой математике и управлении рисками. Наряду с известными учеными докладчиками выступили также и аспиранты.

Симпозиум доставил своим участникам большое удовольствие. Помимо замечательных научных сообщений и дискуссий можно было насладиться прогулками по красивым аллеям на территории Уханьского университета и полюбоваться его историческими зданиями. В заключительные дни симпозиума, которые выдались на редкость туманными и дождливыми, участники отправились на экскурсию в горы Уданшань, всемирно известные своими природными красотами и памятниками всемирного наследия - даосскими монастырями и храмами.

Чжон Ген $С y$, Чжецзянский университет, 